\title{
HYPERBARIC OXYGEN EFFECTS ON CONTRAST AND MACULAR LIGHT SENSITIVITY IN DRY TYPE AGE-RELATED MACULAR DEGENERATION PATIENTS
}

\author{
Indriani Kartika Dewi ${ }^{1 *}$, Moestidjab ${ }^{1}$, Titut Harnanik ${ }^{3}$ \\ ${ }^{1}$ Department of Ophthalmology, Faculty of Medicine, Universitas Airlangga, Surabaya, Indonesia, ${ }^{2}$ Drs Med R \\ Rijadi Sastropanoelar Naval Health Institute, Surabaya, Indonesia
}

\begin{abstract}
This study was to compare the effectiveness of hyperbaric oxygen therapy (HBOT) on contrast and macular light sensitivity improvement in dry type age-related macular degeneration (AMD) patients. The subjects were eyes that had been diagnosed with dry type AMD which met inclusion criteria. The subjects were divided into two groups. The first group was given antioxidants and HBOT. The second group was given only antioxidants. Contrast and macular light sensitivity test were done using MARS contrast sensitivity chart and Humphrey Field Analyzer-3 for three times, pre-therapy, day-1 and 14 post- therapy. This study found that 25 eyes were included for analysis, 14 subjects in first group, and 11 subjects in second group. Statistical analysis results showed that there were significant increase on contrast sensitivity in intervention group between one-day posttherapy with pre-therapy, $P=0.003$ ( $P<0.05)$, and between 14-days post-therapy with pre-therapy, $P=0,015(P<0.05)$. From pre-and post-analysis, there were no significant difference found on contrast sensitivity in control group and macular light sensitivity in intervention group. In control group, there were significant increase on superotemporal, superonasal, and inferonasal area between one-day post-therapy and pra-therapy with $P=0.004, P=0.013$ and $P=0.008(P<0.05)$, respectively, and there was significant decrease on inferonasal area between 14-days post-therapy and one-day post-therapy, $P$ $=0.003(P<0.05)$. In conclusion, patients with AMD who were subjected to HBOT achieved improvement in contrast sensitivity in cases considered as having low prognosis. HBOT should be considered as promising intervention for AMD management adjuvant and further research are needed to find optimal dosage.
\end{abstract}

Keywords: AMD; hyperbaric oxygen; contrast sensitivity; light sensitivity

\section{ABSTRAK}

Penelitian ini bertujuan untuk membuktikan pengaruh dari terapi oksigen hiperbarik pada perbaikan sensitivitas kontras dan cahaya makula pada penderita Age-related Macular Degeneration (AMD) tipe kering. Subjek adalah mata penderita yang telah terdiagnosis AMD tipe kering yang memenuhi kriteria inklusi. Subjek dibagi ke dalam dua kelompok. Kelompok pertama diberikan antioksidan dan HBOT. Kelompok kedua diberikan antioksidan saja. Sensitivitas kontras dan cahaya makula diperiksa menggunakan grafik sensitivitas kontras MARS dan Humphrey Field Analyzer-3. Pemeriksaan dilakukan sebanyak tiga kali, praterapi, satu hari dan 14 hari pascaterapi. Dalam penelitian ini, 25 mata dimasukkan untuk dianalisis, 14 pada kelompok pertama dan 11 pada kelompok kedua. Hasil analisis statistik menunjukkan didapatkan peningkatan yang signifikan pada sensitivitas kontras di kelompok pertama antara satu hari pascaterapi dengan praterapi, $P=0,003(P<0,05)$, dan antara 14 hari pascaterapi dengan praterapi, $P=0,015(P<0,05)$. Pada analisis pre-dan post-, tidak didapatkan perbedaan yang signifikan pada sensitivitas kontras di kelompok kedua dan sensitivitas cahaya makula di kelompok pertama. Pada kelompok kedua didapatkan peningkatan yang signifikan pada area superotemporal, superonasal, dan inferonasal antara satu hari pascaterapi dengan praterapi dengan $P=0,004, P=0,013, P=0,008(P<0,005)$ secara berurutan, dan didapatkan penurunan yang signifikan pada area inferonasal antara 14 hari pascaterapi dan satu hari pascaterapi, $P=0,003(P<0,05)$. Sebagai simpulan, pasien dengan AMD yang menjalani HBOT mengalami perbaikan sensitivitas kontras pada kasus yang dianggap memiliki prognosis buruk. HBOT dapat dijadikan pilihan intervensi yang menjanjikan pada tatalaksana tambahan AMD dan penelitian lanjutan dibutuhkan untuk menemukan dosis yang optimal.

Kata kunci: AMD; oksigen hiperbarik; sensitivitas kontras; sensitivitas cahaya

Correspondence: Indriani Kartika Dewi, Ophthalmology Study Programme, Faculty of Medicine, Universitas Airlangga, Jalan Mayjend Prof. Dr. Moestopo No. 6-8, Gubeng, Surabaya, East Java 60285 Indonesia. Email: indri.kd@gmail.com

pISSN:2355-8393 • eISSN: 2599-056x • doi: 10.20473/fmi.v57i1.9310

- Fol Med Indones. 2020;57:34-40 • Received 6 Aug 2018 • Accepted 14 Feb 2019

- Open access under CC-BY-NC-SA license • Available at https://e-journal.unair.ac.id/FMI/ 


\section{INTRODUCTION}

Age-related macular degeneration (AMD) is the leading cause of blindness in the developed world in people over 50 years of age (McCannel et al 2017). There are two forms of AMD which are dry and wet form. The dry form accounts for approximately 85 to $90 \%$ of AMD cases (Chandramohan et al 2016). It is estimated that among North Americans, 15 million (85\%-90\% of all AMD patients) currently have dry (nonneovascular, or nonexudative) AMD and 1.7 million people (10\%$15 \%$ of all AMD patients) have wet (neovascular) AMD (McCannel et al 2017). Age-Related Eye Disease Study (AREDS) divide AMD into 4 categories according to the size and extent of drusen in each eye, the presence of advanced AMD and visual acuity. AREDS AMD category 1 consisted of persons free of AMD with less than 5 small drusen $(<63 \mu \mathrm{m})$. Category 2 participants had early AMD with multiple small drusen or nonextensive intermediate drusen (63 to $124 \mu \mathrm{m}$ ), pigment abnormalities or a combination of the two. Category 3 participants had no advanced AMD but had at least 1 large drusen $(125 \mu \mathrm{m})$, extensive area of intermediate drusen or geographic atrophy (GA) not involving the center of macula. Category 4 participants had advanced AMD, central geographic atrophy (CGA) or neovascular AMD in one eye (Chew et al 2013).

A previous research has suggested several aspects of macular visual function can be impaired in early AMD, both cone-mediated and rod-mediated functions. These include spatial contrast sensitivity, visual acuity under low luminance and/or low contrast, photopic and scotopic light sensitivity, flicker sensitivity and dark adaptation (Owsley et al 2015). Contrast sensitivity is a measure of the amount of lightness or darkness an object has compared with its background. Although there is a moderate correlation between visual acuity and CS, they are independent measures of visual function and not necessarily interchangeable. Contrast sensitivity can detect visual dysfunction that is not apparent when visual acuity alone is tested (Faria et al 2015). Photoreceptor degeneration in early AMD is associated with decreased light sensitivity in the macula and slowed dark adaptation despite normal visual acuity (Sevilla et al 2016).

AREDS first established the benefit of vitamin and zinc supplementation in reducing the risk of vision loss in nonexudative AMD. In the study, supplementation with the antioxidant vitamins C (500 mg) and E (400 IU), beta carotene $(15 \mathrm{mg})$, and the micronutrient zinc ( 80 $\mathrm{mg}$ zinc oxide and $2 \mathrm{mg}$ cupric oxide to prevent zincinduced anemia) in patients with intermediate or advanced AMD showed a $25 \%$ risk reduction for progression to more-advanced stages of AMD and a
$19 \%$ risk reduction in rates of moderate vision loss $(>=3$ lines of visual acuity) at 5 years (McCannel et al 2017).

In dry AMD, Stefansson et al suggested that the diffusion of oxygen to photoreceptors would be impaired by drusen, and that merely the increased distance of the photoreceptors from the choroid could be significant in causing retinal hypoxia (Stefansson et al 2011). This conclusion was based largely on the analysis of retinal detachment, in which we showed that even very small detachments could impair O2 transport. While it is not easy to know the causal relationship, photoreceptor loss is localized to areas of large drusen (Sadigh et al 2013), so this appears to be a reasonable suggestion.

Hyperbaric oxygen therapy (HBOT) has many biologic affects including activation of endogenous antioxidants, decrease in lipid peroxidation, microbicidal actions, and as a regulator of inflammation, which may theoretically affect the development and/or progression of AMD. A study by Weiss on 14 patients with advanced AMD that was given a one-hour session of HBOT had resulted eight patients were treated at 1.75 ATA, and six patients were treated at 1.5 ATA for one hour. Significant improvements in visual acuity and/or visual field with improvements in the activities of daily living were observed. There were no complications, and the visual benefits achieved appear to be maintained at follow-up visits (Weiss 2010). HBOT dosage that was used at Department of Hyperbaric, Naval Health Institute, Surabaya, Indonesia was breathing $100 \%$ oxygen at 2.4 ATA (Widodo et al 2016).

\section{MATERIALS AND METHODS}

This quasi-experimental study was conducted at Department of Hyperbaric, Naval Health Institute, Surabaya and vitreoretinal division of ophthalmology outpatient clinic at Dr Soetomo Hospital Surabaya from April 2018 to July 2018. This study was approved by Medical Research Ethic Comittee of Dr Soetomo Academic Hospital Surabaya. Informed consent was obtained from participants after the nature and purpose of the study was described.

Patients could be eligible if 1 or both eyes met the following criteria: patients with previously known dry type AMD, visual acuity less than 1.3 LogMAR, systolic blood pressure was below $140 \mathrm{mmHg}$, no abnormalities on ear-nose-throat and chest x-ray examination, agreed to have a restrictive diet (low fat and no alcohol), and if the patient was a smoker, he/she agreed to stop smoking for minimum 4 days before therapy until 1 day after therapy. Participants also asked to avoid sunlight exposure for minimum 4 days before 
therapy until 1 day after therapy. Diagnosis of dry type AMD was based on AREDS classification stage 1,2, and 3 . The diagnosis were confirmed by two vitreoretinal senior consultants. Exclusion criteria included any of the following: having chronic restrictive pulmonary disease, wet type AMD, maculopathy caused by other disease, and inability to read. Drop out criteria were unable to follow the follow-up schedule, refusal to complete the study, and death.

\section{Functional Testing}

Visual acuity and all functional tests were performed before fundus imaging. Best-corrected visual acuity was assessed by one refractionist using ETDRS (Early Treatment of Diabetic Retinopathy) Chart under photopic conditions (189-377 lux). The results were recorded in logarithm of the minimum angle of resolution (logMAR). Subjects wore their best correction for all tests.

Contrast sensitivity testing with MARS numeral contrast sensitivity chart. The test system was a set of three printed charts, supplied in three forms for independent left eye, right eye and binocular testing. The three forms, whose number was identified at the bottom of each chart were identical except for the sequence of numerals. Each chart form consists of 48 numerals, each subtending $2 \mathrm{deg}$ at a $50 \mathrm{~cm}$ test distance, arranged in eight rows of six numerals each. The contrast of each numeral, reading from left to right, and continuing on successive lines, decreased by a constant factor (0.04 log unit). The patient simply read the numerals across lines and down the chart as in standard letter acuity measurement. Instead of the numerals decreasing in size, however they decreased in contrast. The contrast of the final numeral before which the patient misidentified two consecutive numerals with a correction for earlier incorrect responses, determined the log contrast sensitivity (CS).

This study used static automated white-on-white threshold perimetry with Humphrey Field Analyzer-3 (Carl Zeiss Meditec), and 10-2 Swedish Interactive Threshold Algorithm (SITA) Standard Test to examine macular light sensitivity. When the fixation lost and the false-positive/false-negative rates were less than $20 \%$, the results were considered reliable. This study analysed only use the reliable test data. All tests were done for three times, namely baseline (before therapy), one day post therapy, and 14 days post therapy.

\section{Statistical Analysis}

The data obtained were analyzed with frequency and descriptive statistics. The comparison between groups were assessed using Mann-whitney and independent samples T-test. For pre- and post- analyses were using Wilcoxon signed rank test. Qualitative data were analyzed using chi square and Fisher's exact test. All statistical values were considered significant if $\mathrm{p}$ value was < 0.05. All statistical analyses were carried out using SPSS version 20.0.

\section{RESULTS}

Table 1 presented the demographic characteristics of 25 eyes from 15 AMD patiens enrolled in the study. There were no statistically significant difference between both groups' demographic characteristics with $\mathrm{P}>0.05$.

Table 1. Demographic characteristics of the study population

\begin{tabular}{llll}
\hline & $\begin{array}{l}\text { HBOT } \\
(\mathbf{n = 1 4})\end{array}$ & $\begin{array}{l}\text { Cont } \\
\text { rol } \\
(\mathbf{n = 1 1})\end{array}$ & $\begin{array}{l}\mathbf{p} \\
\text { value }\end{array}$ \\
\hline Gender (M/F) & $0 / 14$ & $0 / 11$ & - \\
Age $(\mathrm{y})$ & $64.50 \pm 8.57$ & $64.36 \pm 6.36$ & 0.965 \\
$\begin{array}{l}\text { Diabetes }(\mathrm{Y} / \mathrm{N}) \\
\text { Hypertension }\end{array}$ & $4 / 10$ & $8 / 3$ & 0.073 \\
$(\mathrm{Y} / \mathrm{N})$ & $2 / 12$ & $4 / 7$ & 0.350 \\
Obesity $(\mathrm{Y} / \mathrm{N})$ & $6 / 8$ & $3 / 8$ & 0.677 \\
\hline
\end{tabular}

*p was significant if $<0.05$

M: male, F: female, y: years, Y: yes, N: no

Table 2 presented contrast sensitivity value on both groups at different times. The mean $\log C S$ at baseline was $1.47 \pm 0.28$ and $1.51 \pm 0.13 \log \mathrm{CS}$ in HBOT and control group respectively $(\mathrm{P}=0.934$; table 2$)$. At one day post therapy, the corresponding values were $1.57 \pm$ 0.29 and $1.54 \pm 0.15 \log C S(P=0.241)$, and at 14 days post therapy, they were $1.57 \pm 0.25$ and $1.52 \pm 0.15(\mathrm{P}=$ 0.098). There were no statistically significant differences in contrast sensitivity between groups. Subjects in HBOT group had statistically significant contrast sensitivity improvement at one day and 14 days follow-up ( $\mathrm{P}=0.03$ and 0.015 , respectively, table 3 ). Subjects in control group had no statistically significant contrast sensitivity improvement either at one day or 14 days follow-up compared to baseline $(\mathrm{P}=0.553,0.720$, respectively).

Table 2. Contrast sensitivity values during the course of the study

\begin{tabular}{lcccccc}
\hline Time & Mean & SD & Median & Min. & Max. & $\begin{array}{l}\mathbf{p} \\
\text { value }\end{array}$ \\
\hline $\begin{array}{l}\text { Baseline: } \\
\text { HBOT }\end{array}$ & 1.47 & 0.28 & 1.56 & 0.64 & 1.68 & 0.934 \\
$\begin{array}{l}\text { control } \\
\begin{array}{l}\text { day } \\
\text { post- } \\
\text { therapy: }\end{array}\end{array}$ & 1.51 & 0.13 & 1.48 & 1.30 & 1.72 & \\
& 1.57 & 0.29 & 1.68 & 0.64 & 1.76 & 0.241
\end{tabular}




\begin{tabular}{lllllll} 
HBOT & 1.54 & 0.15 & 1.52 & 1.28 & 1.72 & \\
$\begin{array}{l}\text { control } \\
14 \text { days }\end{array}$ & & & & & & \\
$\begin{array}{l}\text { post } \\
\text { therapy: }\end{array}$ & 1.57 & 0.25 & 1.68 & 0.88 & 1.76 & 0.098 \\
$\begin{array}{l}\text { HBOT } \\
\text { Control }\end{array}$ & 1.52 & 0.15 & 1.56 & 1.24 & 1.68 & \\
\hline
\end{tabular}

*p was significant if $<0.05$

SD: standard deviation

Table 3. Contrast sensitivity changes

\begin{tabular}{lll}
\hline \multirow{2}{*}{ Time } & $\mathrm{p}$ value \\
\cline { 2 - 3 } & $\mathrm{HBOT}$ \\
\hline 1 day post therapy - baseline & $0.003^{*}$ & \\
14 days post therapy - baseline & $0.015^{*}$ & \\
14 days post therapy -1 day post therapy & 0.731 & T \\
\hline * $\mathrm{p}$ was significant if $<0.05$ & &
\end{tabular}

Table 4 presented macular light sensitivity values on both groups at different times. The macular light sensitivity was divided into 4 areas, which were superotemporal, superonasal, inferotemporal, and inferonasal, as seen in figure 1 . The mean value in each area was stated in table 4 .

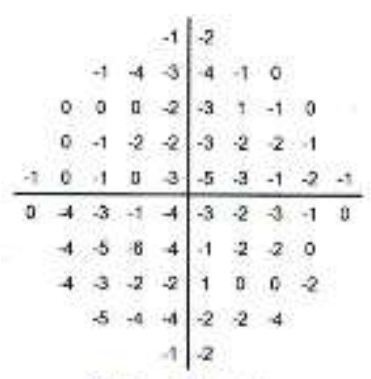

Pattern Deviation
Figure 1. Humphrey Field Analyzer-3 (10-2 pattern, SITA stando.:5बके pattern deviation results 0.720

There were $.23{ }^{7}$ statistically significant difference found between both groups in every areas and times $(\mathrm{P}>0.05$; Table 4).

Table 4. Macular light sensitivity values during the course of the study 


\begin{tabular}{|c|c|c|c|c|c|c|}
\hline & Mean & SD & Median & Min. & Max. & $\mathrm{p}$ value \\
\hline \multicolumn{7}{|c|}{ Superotemporal } \\
\hline \multicolumn{7}{|c|}{ Baseline: } \\
\hline HBOT & -2.87 & 3.70 & -1.44 & -14.65 & -0.47 & \multirow{2}{*}{$0.084^{\ddagger}$} \\
\hline Control & -3.03 & 1.43 & -2.59 & -5.53 & -1.24 & \\
\hline \multicolumn{7}{|c|}{ One day post therapy: } \\
\hline HBOT & -2.77 & 4.20 & -1.35 & -16.06 & -0.18 & \multirow[t]{2}{*}{0.784} \\
\hline Control & -1.53 & 0.76 & -1.41 & -3.53 & -0.71 & \\
\hline \multicolumn{7}{|c|}{14 days post therapy: } \\
\hline HBOT & -2.81 & 3.39 & -1.59 & -13.35 & -0.53 & \multirow[t]{2}{*}{$0.366^{\ddagger}$} \\
\hline Control & -2.54 & 1.83 & -2.29 & -7.53 & -0.59 & \\
\hline \multicolumn{7}{|c|}{ Superonasal } \\
\hline Baseline & & & & & & \multirow{3}{*}{$0.155^{\dagger}$} \\
\hline HBOT & -1.98 & 1.39 & -1.53 & -4.47 & -0.35 & \\
\hline Control & -2.99 & 2.08 & -2.82 & -6.65 & -0.71 & \\
\hline \multicolumn{7}{|c|}{ One day post therapy: } \\
\hline НBOT & -2.08 & 2.10 & -1.06 & -7.76 & -0.29 & \multirow[t]{2}{*}{$0.381^{\ddagger}$} \\
\hline Control & -2.03 & 1.37 & -1.65 & -5.18 & -0.41 & \\
\hline \multicolumn{7}{|c|}{14 days post therapy: } \\
\hline HBOT & -2.49 & 2.46 & -1.71 & -10.06 & -0.59 & \multirow[t]{2}{*}{$0.285^{t}$} \\
\hline Control & -3.04 & 2.00 & -2.59 & -7.12 & -1.12 & \\
\hline \multicolumn{7}{|c|}{ Inferotemporal } \\
\hline Baseline & & & & & & \multirow{3}{*}{$0.661^{+}$} \\
\hline HBOT & -2.76 & 2.80 & -1.85 & -11.41 & -0.53 & \\
\hline Control & -2.13 & 1.33 & -1.94 & -4.71 & -1.00 & \\
\hline \multicolumn{7}{|c|}{ One day post therapy: } \\
\hline HBOT & -3.05 & 3.82 & -1.91 & -15.12 & -0.53 & \multirow[t]{2}{*}{$0.956^{\ddagger}$} \\
\hline Control & -1.99 & 0.79 & -1.88 & -3.82 & -0.82 & \\
\hline \multicolumn{7}{|c|}{14 days post therapy: } \\
\hline НBOT & -2.94 & 3.55 & -1.82 & -14.65 & -1.12 & \multirow[t]{2}{*}{$0.826^{\ddagger}$} \\
\hline Control & -2.41 & 1.55 & -1.59 & -5.41 & -0.94 & \\
\hline \multicolumn{7}{|c|}{ Inferonasal } \\
\hline Baseline & & & & & & \\
\hline HBOT & -1.99 & 1.30 & -1.38 & -5.12 & -1.00 & \multirow[t]{2}{*}{$0.198^{\ddagger}$} \\
\hline Control & -2.66 & 2.07 & -2.12 & -8.24 & -0.88 & \\
\hline \multicolumn{7}{|c|}{ One day post therapy: } \\
\hline HBOT & -1.97 & 1.16 & -1.88 & -5.06 & -0.47 & \multirow[t]{2}{*}{$0.213^{\dagger}$} \\
\hline Control & -1.50 & 0.46 & -1.59 & -2.35 & -0.94 & \\
\hline \multicolumn{7}{|c|}{14 days post therapy: } \\
\hline HBOT & -2.18 & 1.08 & -2.17 & -3.94 & -0.71 & \multirow[t]{2}{*}{$0.78^{\dagger}$} \\
\hline Control & -2.30 & 1.01 & -2.24 & -4.24 & -1.00 & \\
\hline
\end{tabular}

*p was significant if $<0.05$

$\dagger$ Based on independent samples T-test

$\$$ Based on Mann-whitney test

Table 5. Macular light sensitivity changes

\begin{tabular}{lll}
\hline Time & p value & \\
\hline Superotemporal : & HBOT & Control \\
1 day post therapy - baseline & 0.489 & $0.004^{*}$ \\
14 days post therapy - baseline & 0.900 & 0.154 \\
14 days post therapy - 1 day post therapy & 0.330 & 0.062 \\
Superonasal : & & \\
1 day post therapy - baseline & 0.900 & $0.013^{*}$ \\
14 days post therapy - baseline & 0.221 & 0.722 \\
14 days post therapy - 1 day post therapy & 0.096 & 0.109 \\
Inferotemporal : & & \\
1 day post therapy - baseline & 0.625 & 0.563 \\
14 days post therapy - baseline & 0.889 & 0.689 \\
14 days post therapy - 1 day post therapy & 0.850 & 0.504 \\
Inferonasal : & & \\
1 day post therapy - baseline & 0.807 & $0.008^{*}$ \\
14 days post therapy - baseline & 0.433 & 0.534 \\
14 days post therapy - 1 day post therapy & 0.505 & $0.003^{*}$ \\
\hline
\end{tabular}

*p was significant if $<0.05$ 
The changes of macular light sensitivity were significantly increased in control group, between 1 day post therapy and baseline at superotemporal, superonasal and inferonasal area $(\mathrm{p}=0.004,0.013$, and 0.008 , respectively, table 5). At inferonasal area, there was statistically significant decrease in macular light sensitivity changes $(p=0.003)$. In HBOT group, although not statistically significant, there were slight improvement in all area between one day post therapy and baseline.

\section{DISCUSSION}

This clinical trial showed benefits of treatment with hyperbaric oxygen for dry type AMD. Most studies on this subject have visual acuity as an endpoint. Our study was the first to use contrast and macular light sensitivity as endpoints. This was based on previous study that stated that visual acuity is inadeaquate as an endpoint for evaluating treatments for early and intermediate AMD since visual acuity is largely undisturbed during these disease stages (Owsley, Huisingh, Clark, Jackson, \& McGwin Jr, 2015).

At one-day follow-up, there were significant improvement on contrast sensitivity in HBOT group, which was in line with previous study by Weiss, showing improvement in visual function 2-days followup after one hour session of HBOT in AMD patients (Weiss, 2010). Keane found that the strongest correlatian detected between decreased contrast sensitivity and increased total volume of subretinal tissue (Keane, et al., 2010). Previous study by Chao stated that HBOT can decrease the release of TNF- $\alpha$ by RPE cells therefore decreased inflammation (Chao \& Chao, 2017). We believed the improvement on contrast sensitivity in our patients were becaused of the decreased inflammation on subretinal tissue by HBOT. At 14-days follow-up, eventhough there were significant improvement compared to baseline, we could not the same results when compared to one-day follow-up. This showed that improvement on contrast sensitivity happened at one-day follow up and it was stable until 14-days follow-up.

Although macular light sensitivity improved in HBOT group during one-day of follow up, the trend was not statistically significant. this can be explained from previous study that stated photoreceptor consumed a large amount of oxygen to convert light energy into readable neuronal signals for the brain to translate (Chao \& Chao, 2017). The pivotal role of oxygen for photoreceptor survival was reported. When retina was exposed by bright light, direct exposure to the sunlight or even by continous ambient light, it activated phototransduction persistently.
This proccess consumed large amount of oxygen and could cause oxidative stress (Panfoli, Calzia, Ravera, Morelli, \& Traverso, 2012). Our subjects in HBOT group had more sunlight exposure than subjects in control group. This was showed in 14-days follow-up results in control group we can see a sugnificant decrease of macular light sensitivity since the restriction on sunlight exposure only until one day of follow up.

A study by Linsenmeier stated that $100 \%$ oxygen could be beneficial if given episodically (Linsenmeier \& Zhang, 2017). In our study, HBOT was only given for one session, with no maintenance dosage. Further research would be needed to investigate the optimal dosage for AMD patients.

Our main bias was lack of patients' blindness. It was impossible to do a true double-blind study because HBOT needs patients to be cooperative. Another limitation of the study was no randomization alocation on subjects due to difficulty to maintain HBOT schedule for people living out of town. Other limitations to the study were short duration of follow-up, and difficulty to control confounding variables (such as diet, sunlight exposure, smoke and air pollution exposure).

\section{CONCLUSION}

In this study 14 subjects with AMD is given HBOT and achieved improvement in contrast sensitivity in cases considered low prognosis. In summary, our findings reveal some beneficial effects of hyperbaric oxygen for the adjuvant management of early and intermediate AMD compared to antioxidant only. HBOT should be considered as promising intervention for AMD management adjuvant and further research are needed to find optimal dosage.

\section{REFERENCES}

Chandramohan A, Stinnett SS, Petrowski JT, Schuman SG, Toth CA, Cousins SW, Lad EM (2016). Visual function measures in early and intermediate agerelated macular degeneration. Retina 36, 1021-1031.

Chao CS, Jie L, Chao JK (2017). The effect of neovascularization on human retinal pigment epithelium after hyperbaric oxygen therapy. Health Sci J 11, 535.

Chew EY, Clemons TE, Agron E, Sperduto RD, SanGiovanni JP, Kurinij N, Davis MD, For the Agerelated Eye Disease Study Research Group (2013). Long-term effects of vitamin C, E, beta-carotene and 
zinc on age-related macular degeneration. AREDS Report No 35. Ophthalmology 120, 1604-1611.

Faria BM, Duman F, Zheng CX, Waisbourd M, Gupta L, Ali M, Zangalli C, Lu L Sheryl SW, Spaeth E, Richman J, Spaeth GL (2015). Evaluating contrast sensitivity in age-related macular degeneration using a novel computer-based test, the Spaeth/Richman contrast sensitivity test. Retina 35, 1465-1473.

Keane PA, Patel PJ, Ouyang Y, Chen FK, Ikeji F, Walsh AC, Tufail A, Sadda SR (2010). Effects of retinal morphology on contrast sensitivity and reading ability in neovascular age-related macular degeneration. Invest Ophthalmol Vis Sci 51, 54315437.

Linsenmeier RA, Zhang HF (2017). Retinal oxygen: from animals to humans. Prog Retin Eye Res 58, 115151.

McCannel CA, Atebara NH, Kim SJ, Leonard BC, Rosen RB, Sarraf D, Cunningham E, Holder GE (2017). Basic and clinical science course: retina and vitreous. San Fransisco, American Academy of Ophthalmology.

Owsley C, Huisingh C, Clark ME, Jackson GR, McGwin Jr G (2015). Comparison of visual function in older eyes in the earliest stages of age-related macular degeneration to those in normal macular health. Curr Eye Res 41, 266-272.

Panfoli I, Calzia D, Ravera S, Morelli AM, Traverso CE (2012). Extra-mitochondrial aerobic metabolism in retinal rod outer segments: new perspectives in retinopathies. Med Hypotheses 78, 423-427.

Sadigh S, Cideciyan AV, Sumaroka A, Huang WC, Luo X, Swider M, Steinberg JD, Stambolian D, Jacobson SG (2013). Abnormal thickening as well as thinning of the photoreceptor layer in intermediate age-related macular degeneration. Invest Ophthalmol Vis Sci 54, 1603-1612.

Sevilla MB, McGwin Jr G, Lad EM, Clark M, Yuan EL, Farsiu S, Curcio CA, Owsley C, Toth CA (2016). Relating retinal morphology and function in aging and early to intermediate age-related macular degeneration subjects. Am J Ophthalmol 165, 65-77.

Stefansson E, Geirsdottir A, Sigurdsson H (2011). Metabolic physiology in age related macular degeneration. Prog Retin Eye Res 30, 72-80.

Weiss JN (2010). Hyperbaric oxygen therapy and agerelated macular degeneration. Undersea Hyperb Med 37, 101-105.

Widodo D, Hisnindarsyah, Harnanik T (2016). Buku ajar ilmu kesehatan penyelaman dan hiperbarik. Surabaya, Drs Med R Rijadi Sastropanoelar Naval Health Institute. 